\title{
Investigation of Patient Awareness and Attitude in Dermatology
}

\author{
Melek Aslan Kayıran $^{1}$ (iD , İlknur Özcan ${ }^{1}$ (D) , Mehmet Salih Gürel ${ }^{1}$ (iD
}

${ }^{1}$ Istanbul Medeniyet University, School of Medicine, Göztepe Prof. Dr. Süleyman Yalçın City Hospital, Departments of Dermatology and Venereology, Istanbul, Turkey

\section{Melek ASLAN KAYIRAN, MD}

İlknur ÖZCAN, MD

Mehmet Salih GÜREL, MD, Prof.
Correspondence: Melek Aslan Kayıran İstanbul Medeniyet University, School of Medicine, Prof Dr Süleyman Yalçın City Hospital, Departments of Dermatology and Venereology, Istanbul, Turkey

Phone: +902165664000

E-mail:melekaslan@gmail.com
Received
: 20 February 2021
Accepted
: 01 May 2021

\section{ABSTRACT}

Purpose: It is known that patients seek to obtain medical information about diseases from the internet before coming to a doctor. Patients' knowledge of dermatological diseases or thoughts on complementary and alternative treatment (CAT) have not been investigated. It was aimed to investigate the concept of health literacy, such as the level and source of knowledge and prejudices in our country.

Methods: Nine multiple choice questions related to conditions that can cause skin diseases, reasons for applying to dermatology, which dermatological diseases they know, the department they apply for sexually transmitted diseases, diseases that can be transmitted by contact, whether they have done CAT, whether they do research the skin diseases on internet, and true-false questions regarding 14 different dermatology myths were asked.

Results: The vast majority of patients thought that the cause of skin diseases was stress. Fungal and parasitic diseases were mostly marked in response to contagious diseases. They often referred to urology and gynecology departments for sexually transmitted diseases. While $29 \%$ of the patients had CAT, $63.7 \%$ had researched their diseases on internet before consulting a doctor. The vast majority thought that they could sunbathe after applying sunscreen.

Conclusion: The patients had a lack of knowledge about contagious diseases and sunscreen use. It was not the first choice to apply to the dermatology in sexually transmitted diseases. While searching information about their disease on internet is very common, the vast majority of patients relied on the doctor's advice.

Keywords: attitude, dermatology, internet, knowledge, patients

\section{Dermatolojide Hasta Farkındalığının ve Tutumunun İncelenmesi}

ÖZET

Amaç: Hastalar hekime gelmeden önce hastalıkları konusunda internetten araştııı tıbbi bilgiler edinmeye çalıştıkları bilinmektedir. Ancak hastaların dermatolojik hastalıklarla ilgili bilgileri veya alternatif ve tamamlayıcı tıp (ATT) hakkındaki düşünceleri araştırılmamıştır. Ülkemizde bu konudaki bilgi düzeyi, bilginin kaynağı ve önyargılar gibi sağlık okuryazarlı̆ı kavramının araştıııması amaçlandı.

Metod: Hastaların cilt hastalıklarına neden olabilecek durumlar, hastaneye başvurma nedenleri, hangi dermatolojik hastalıkları bildikleri, cinsel ilişki ile bulaşan hastalıklarda başvurdukları bölüm, temasla bulaşabilen hastalıklar, ATT yaptııp yaptırmadıkları, cilt hastalıkları ile ilgili internetten araştırma yapıp yapmadıkları ile ilgili dokuz adet çoktan seçmeli ve 14 farklı dermatoloji miti ile ilgili doğru yanlış sorusu anket olarak soruldu.

Bulgular: Hastaların en büyük çoğunluğu deri hastalıklarının nedeninin stres kaynaklı olduğunu düşünmekteydi. Temasla bulaşan hastalıklara cevap olarak daha çok mantar ve paraziter hastalıklar işaretlenmiști. Cinsel yolla bulaşan hastalıklar için sıkıkıla üroloji ve kadın doğum bölümlerine başvuruyorlardı. Hastaların \%29'u ATT yaptırmışken, \%63,7'si doktora başvurmadan önce hastalığını internetten araştırmıştı. Büyük çoğunluğu güneş koruyucu sürerek güneşlenebileceğini düşünüyordu.

Sonuç: Hastaların temasla bulaşabilecek hastalıklar ve güneş koruyucu ile bronzlaşma konusunda bilgi eksikliği vardı. Cinsel yolla bulaşan hastalıklarda dermatoloji polikliniğine başvurmak ilk tercih değildi. İnternetten hastalıkları hakkında bilgi araştırmak çok yaygınken hastaların büyük çoğunluğu doktorunun önerilerine ve bilgisine internetten çok daha fazla güveniyordu.

Anahtar Kelimeler: Bilgi, dermatoloji, hastalar, internet, tutum 
Datients who apply to dermatology outpatient clinics with different causes and symptoms every day request information from their physicians about their diseases or try to have information on their own. However, we do not have much knowledge on how patients behave at a cognitive level about skin health and diseases and from which sources they seek information. Today, social media or media organs are widely used for all kinds of information, including health (1). Patients use not only conventional therapy but also complementary and alternative treatment (CAT) methods (2). Patients may often hurt themselves with incomplete or incorrect information about diseases, causes, treatments, or preventive methods, or lose time for proper treatment.

We conducted a survey study about how much information patients have about skin conditions, how they know their diseases and own diagnosis, what they are aware of, what they have done for these complaints before, whether they have used CAT method, whether they have researched their diseases on internet and social media and what they think about dermatological myths.

\section{Materials and Methods}

Before starting the study, the necessary study approval was obtained from the ethics committee of the University (2019/64). Patient consent was obtained from the patients who participated in the study.

Survey questions were created by the researchers who participated in the study by reviewing and discussing the literature related to the subject. The questions were summarized in Table 1. The questionnaire was answered by individuals who attended to the dermatology outpatient clinic in between March-August 2019.

\section{Statistical Analysis}

SPSS (IBM Corp. Released 2013. IBM SPSS Statistics for Windows, Version 22.0. Armonk, NY: IBM Corp) was used for the statistical analysis. Statistical significance of the difference between common questions was determined with chi-square test, and the effect of different groups on answering the question was analyzed with Cramér's V test. $p$ values below 0.05 were recognized as statistically significant.

\section{Results}

A total of 179 literate people were included in the study. The demographic characteristics of the patients are summarized in Table 2.

\section{Table 1. The main topics of the survey questions}

Do you think dermatology and the skin diseases clinic are the same departments?

For your point of view, what are the causes of the dermatological diseases?

Which dermatological diseases do you know?

Why did you apply to dermatology outpatient clinic?

Do you know the name of your own disease, if so please write.

Did you apply to a family physician or a dermatologist for the same reason that you came our clinic? If so, which one?

Which departments do you apply for sexually transmitted diseases?

Which contagious skin diseases do you know?

Did you had CAT for your dermatologic diseases, if so which ones.

Did you research on dermatological diseases on internet? If so, did you share it with your doctor?

Questions: True or False

Most of the skin diseases are caused by liver disfunction.

Allergy tests should be done for all pruritus/egzema cases.

I may have a sunbathe after I apply sunscreen.

Having tan is good for skin and body health.

Having sunbathe under a tree or umbrella gives no harm.

Herbal products/creams are harmless than the drugs.

Herbal products don't give any harm to our body.

I use the creams which were prescribed to family members before I go to doctor.

I don't like using topical therapy like creams and lotions.

Topical therapies are not effective for diseases.

I don't want to use systemic therapy for skin diseases, they may be harmful for my health.

Some systemic treatments for acne may cause infertility.

Onychomycosis cannot be improved unless the nail excised.

CAT, Complementary and alternative treatment

For the question "Are dermatology and skin diseases clinic the same department?", $13.4 \%$ of the patients said that they were different departments and $7.8 \%$ did not know, while $5 \%$ did not answer the question. Primary education graduates (PEG) thought the two departments were different when compared with higher education graduates (HEG) $(16 \%, 8.3 \%$, respectively, $p=0.018$, .

The answered conditions that may cause dermatological diseases were summarized in Table 3 . Stress (79\%), sunlight (74\%), chemicals (62\%) and microbes (58\%) were the most marked answers. Only $7 \%$ of the patients thought that pregnancy and breastfeeding could cause dermatological diseases. 
Table 2. Distribution of patients' age, gender, educational status, and the number of applications to the outpatient clinic

\begin{tabular}{|l|c|c|c|c|c|c|}
\hline & Female & Male & PEG & HEG & $\leq 40$ & $>40$ \\
\hline $\begin{array}{l}\text { Number- } \\
\text { Percent }\end{array}$ & $\begin{array}{c}107- \\
\% 59.8\end{array}$ & $\begin{array}{c}72- \\
\% 40.2\end{array}$ & $\begin{array}{c}119- \\
\% 66.5\end{array}$ & $\begin{array}{c}60- \\
\% 33.5\end{array}$ & 109 & 70 \\
\hline $\begin{array}{l}\text { Average } \\
\text { Age }\end{array}$ & $\begin{array}{c}35.66 \\
\pm 14.54\end{array}$ & $\begin{array}{c}42.50 \\
\pm 18.98\end{array}$ & $\begin{array}{c}41.01 \\
\pm 17.17\end{array}$ & $\begin{array}{c}33.27 \\
\pm 13.16\end{array}$ & - & - \\
\hline $\begin{array}{l}\text { Minimum } \\
\text { (Min) and } \\
\text { Maximum } \\
\text { (Max) age }\end{array}$ & $16-85$ & $16-79$ & $16-85$ & $19-75$ & - & - \\
\hline $\begin{array}{l}\text { Number of } \\
\text { applications } \\
\text { to the } \\
\text { outpatient } \\
\text { clinic } \\
\text { (Min-Max) }\end{array}$ & $1-60$ & $1-100$ & $1-100$ & $1-14$ & $1-60$ & $1-100$ \\
\hline $\begin{array}{l}\text { Average } \\
\text { number of } \\
\text { applications }\end{array}$ & 13.292 & \begin{tabular}{c}
$6.63 \pm$ \\
\hline Prmary Eductic|
\end{tabular} & $\begin{array}{c}6.94 \pm \\
13.158\end{array}$ & $\begin{array}{c}3.35 \pm \\
3.236\end{array}$ & $\begin{array}{c}3.75 \pm \\
6.521\end{array}$ & $\begin{array}{r}8.83 \\
\hline\end{array}$ \\
\hline
\end{tabular}

Primary Education Graduate (PEG) represents high school and below. Higher Education Graduate (HEG) university college and above, $\leq 40$ represents under or equal 40 years of age group, $>40$ represents over 40 years of age group.

Mycosis (84\%), verruca (82\%), and eczema (82\%) were most commonly known cutaneous diseases. HEG knew hives $(70 \%, 56.3 \%$ respectively, $\mathrm{p}=0.076)$ and verruca $(86.7 \%, 63.9 \%$ respectively, $\mathrm{p}=0.051)$ more than PEG. Over 40 years of age group ( $>40)$, compared to under or equal 40 years of age group $(\leq 40)$ knew statistically significantly more about hives $(72.9 \%, 53.2 \%$, respectively, $\mathrm{p}=0.009)$, leprosy $(54.3 \%, 30.3 \%$, respectively, $\mathrm{p}=0.001)$ and syphilis $(50 \%, 29.4 \%$, respectively, $\mathrm{p}=0.005)$, and women knew acne more than men $(73.8 \%, 51.4 \%$, respectively, $\mathrm{p}=0.000)$.

Women thought that infestation of lice (women $66 \%$, men $34 \%, p=0.040)$, and herpes, $(78 \%, 22 \%, p=0.014$, respectively) and men thought that callus (men $86 \%$, women $14 \%, p=0.012$ ) would transmit significantly. Fungal disease $(58.1 \%)$, and infestation with lice $(59.2 \%)$ were thought to be contagious in general population. Scabies (43\%), warts $(20.7 \%)$, herpes $(20.1 \%)$, and bacterial skin infections (23.5\%) were answered as not contagious. $29.1 \%$ of the patients thought that HIV infection would transmit by touch.

$32 \%$ of the patients knew their skin disease correctly and the majority were women (64\%). $73 \%$ of the patients applied to another physician for the same complaint. $88 \%$ of them went to the dermatologist, the rest to the family doctor and other specialists.
Obstetrics (39.1\%), urology (28.5\%), infectious diseases department (25.7\%) and dermatology (15.6\%) were the departments that patients prefer to apply when having sexually transmitted diseases.

$29 \%$ of the patients had CAT for their dermatologic diseases. Cupping (9.5\%), leech (3.4\%), acupuncture (2.8\%), ozone therapy $(1.1 \%)$ were performed, nobody had hypnotherapy. Women preferred cupping (10.3\%), leech (3.7\%) and acupuncture (3.7\%) while males preferred cupping (8.4\%) and leech (2.8\%).

\begin{tabular}{|c|c|c|c|c|c|c|c|c|c|}
\hline Reasons & $\begin{array}{c}\text { Male } \\
\%\end{array}$ & $\begin{array}{c}\text { Female } \\
\%\end{array}$ & $\begin{array}{c}P \\
\text { value }\end{array}$ & $\begin{array}{c}\text { PEG } \\
\%\end{array}$ & $\begin{array}{c}\text { HEG } \\
\%\end{array}$ & $\begin{array}{c}P \\
\text { value }\end{array}$ & $\begin{array}{c}\leq 40 \\
\%\end{array}$ & $\begin{array}{c}>40 \\
\%\end{array}$ & $\begin{array}{c}P \\
\text { value }\end{array}$ \\
\hline stress & 37 & 63 & 0.213 & 64 & 36 & 0.018 & 64 & 36 & 0.222 \\
\hline $\begin{array}{l}\text { liver } \\
\text { disease }\end{array}$ & 34 & 66 & 0.005 & 58 & 42 & 0.213 & 60 & 40 & 0.907 \\
\hline food & 30 & 70 & 0.006 & 60 & 40 & 0.005 & 68 & 32 & 0.007 \\
\hline sunlight & 35 & 65 & 0.212 & 64 & 36 & 0.006 & 59 & 41 & 0.239 \\
\hline $\begin{array}{l}\text { air } \\
\text { pollution }\end{array}$ & 40 & 60 & 0.009 & 56 & 44 & 0.212 & 66 & 34 & 0.405 \\
\hline microbes & 37 & 63 & 0.001 & 56 & 44 & 0.009 & 69 & 31 & 0.027 \\
\hline drugs & 30 & 70 & 0.053 & 59 & 41 & 0.001 & 67 & 33 & 0.145 \\
\hline chemicals & 39 & 61 & 0.161 & 62 & 38 & 0.053 & 61 & 39 & 0.864 \\
\hline genetics & 38 & 62 & 0.000 & 50 & 50 & 0.161 & 70 & 30 & 0.027 \\
\hline $\begin{array}{l}\text { visceral } \\
\text { diseases }\end{array}$ & 44 & 56 & 0.022 & 56 & 44 & 0.000 & 62 & 38 & 0.908 \\
\hline hormones & 31 & 69 & 0.003 & 56 & 44 & 0.022 & 67 & 33 & 0.112 \\
\hline old age & 42 & 58 & 0.213 & 58 & 42 & 0.003 & 60 & 40 & 0.805 \\
\hline smoking & 40 & 60 & 0.112 & 62 & 38 & 0.213 & 66 & 34 & 0.144 \\
\hline alcohol & 40 & 60 & 0.095 & 60 & 40 & 0.112 & 68 & 33 & 0.105 \\
\hline insomnia & 27 & 73 & 0.056 & 56 & 44 & 0.095 & 73 & 27 & 0.047 \\
\hline dirty ware & 35 & 65 & 0.055 & 60 & 40 & 0.056 & 69 & 31 & 0.078 \\
\hline $\begin{array}{l}\text { contact } \\
\text { with } \\
\text { people }\end{array}$ & 32 & 68 & 0.537 & 63 & 37 & 0.055 & 61 & 39 & 0.960 \\
\hline $\begin{array}{l}\text { pregnancy } \\
\text { lactation }\end{array}$ & 15 & 84 & 0.001 & 23 & 77 & 0.537 & 77 & 23 & 0.242 \\
\hline $\begin{array}{l}\text { contact } \\
\text { with } \\
\text { animals }\end{array}$ & 45 & 55 & 0.126 & 74 & 26 & 0.001 & 55 & 45 & 0.384 \\
\hline $\begin{array}{l}\text { I don't } \\
\text { know }\end{array}$ & 67 & 33 & 0.372 & 83 & 17 & 0.126 & 100 & 0 & 0.053 \\
\hline other & 0 & 100 & 0.636 & 50 & 50 & 0.372 & 50 & 50 & 0.729 \\
\hline \multicolumn{10}{|c|}{$\begin{array}{l}\text { When considering in terms of gender, liver diseases, food, air pollution, microbes, genetic factors, } \\
\text { visceral diseases, hormones and pregnancy-lactation were statistically significant in favor of } \\
\text { women. When considering in terms of educational status, stress, food, sun, germs, drugs, visceral } \\
\text { diseases, hormones, old age and animal contact options were statistically significant in favor } \\
\text { of PEG. Considering by the age groups, food, microbes, genetics, insomnia were statistically } \\
\text { significantly higher at } \leq 40 \text {. }\end{array}$} \\
\hline
\end{tabular}


$64 \%$ of the patients had searched their diseases on the internet. All of the patients who researched did it through Google. 13\% stated that they also used Facebook and Instagram. Internet use rate was significantly higher in $\leq 40$ group (70\%) than $>40$ group (53\%) $(p=0.016)$. $34 \%$ of the patients did not ask the physicians about the information they found on the internet.

$78 \%$ said they would trust their physicians, but $9 \%$ would consult another physician if they read in the internet research conflict with what the physician said.

We also asked about the common public beliefs about dermatology. The majority of the patients (35\%) thought that liver disfunction may cause skin diseases. The patients believed that allergy tests should be done to the patients with pruritus (64\%) and eczema (31\%). The patients thought that they could sunbathe after applying sunscreen $(61 \%)$ and under an umbrella (35\%), and $15 \%$ thought that tanning was beneficial for skin. The percentage of patients who thought that the herbal products are less harmful than the drugs given by the doctor was $10 \%$ and $11 \%$ thought that the herbal products would not give any harm to the body. $7 \%$ of the patients used creams at home or took from someone else for their diseases before going to the hospital. $26 \%$ of the patients stated that they do not like to use topical treatment. $20 \%$ of the patients thought that topical treatments did not work, using systemic treatment for skin diseases harmed the body, and some systemic acne medications may cause infertility. $10 \%$ believed that the nails should be excised for successful treatment of onychomycosis. Considering inter-group differences, men $(p=0.026)$ thought that that topical treatments do not work, PEG $(p=0.001, p=0.035$, respectively) thought that the sunlight will not harm under the umbrella or tree, the fungus will not heal without nail excising in onychomycosis, and those who thought that an allergy test should be performed at each itching diseases and those who did not want to use systemic treatment for dermatological diseases were more frequently in $\leq 40$ groups ( $p=0.024, p=0.002$, respectively). There was no statistically significant difference between the groups in other answers.

\section{Discussion}

In our country, a complete consensus has not occurred in the name of skin diseases branch. The question of "Are you a dermatologist or a skin doctor?" is asked by patients every day. Also, the fact that the official specialty name of the department is "Skin and Venereal Diseases" complicates this situation. As a result, the perception of patients and their application to physicians are affected in our society. However, as the education level increased, it became clear that the patients are sure about all names belong to the same department..

There are many factors that can cause dermatological diseases. Among these, many causes such as drugs, physical activities, internal organ diseases, old age, microorganisms, chemicals, sun, climatic conditions, allergies, pregnancy, psychological factors can be counted (3-5). Although the etiology in each disease differs, it is not correct to say that psychological factors are the highest cause in etiology as our patients think. However, almost every dermatologist encounters many psychosomatic complaints both due to the disease and due to the psychological distress caused by the dermatological event $(6,7)$. For this reason, it is important for dermatologists to understand patient psychology well and establish the necessary communication with the patient. It is known to us, dermatologists, that there are sections about pregnancy dermatoses in dermatology books and there are some skin diseases that are seen only during pregnancy (8). If we consider these, it is interesting that patients do not count pregnancy and breastfeeding as factors that can cause skin diseases. The reason for this may be that these diseases are not as common in the society as other skin diseases.

When we look at the frequency of the diagnoses of patients who applied to the dermatology outpatient clinic, depending on the age of the patient, geographic area and health institution, the most common ones are eczema, skin infections and acne vulgaris $(9,10)$. Our patients often knew fungal diseases of the skin and eczema. Women (\%73.8) knew and remembered acne vulgaris disease more than men (\%51.4). As the reasons for applying to the outpatient clinic, the patients mostly applied due to itching, rash and acne.

Contagious diseases are serious health problems in both developing and developed countries. If we look at skin diseases, fungal, bacterial, viral and parasitic infections can be transmitted by contact (11). In addition, antibiotic resistance strains has also been shown to be transmitted by contact (12). For this reason, measures such as educating the society in terms of contact diseases, frequent washing of the hands, keeping the infectious area covered, and reducing the use of common goods prevent the spread of these infections and antibiotic resistance strains (13). However, in order to be protected, it is necessary to know 
that these diseases are contagious. According to the results of our study, it is seen that our society needs to be educated on this subject.

The patients may apply to many different branches for sexually transmitted diseases (14). One of these branches is dermatology. However, only $16 \%$ of the patients thought they would apply to the dermatologist with this complaint. Therefore, it is seen that it is not fully known that dermatology is a branch that deals with sexually transmitted diseases in our country.

As in the whole world, there are many patients who have applied CAT in our country. Dermatological diseases were not excluded from this trend. While patients who have applied CAT for dermatological diseases worldwide are $35-69 \%$, this rate varies between $12.6-52.1 \%$ in our country (15-17). In the present study, this rate was determined to be $29 \%$ and similar to the other studies done in our country. There could be some geographical changes for CAT use even in different regions of the countries. This situation seems to explain the differences in percentages in different countries. While the most commonly used methods in our country are topical herbal treatments, prayer and balneotherapy methods, those used all over the world are herbal treatments, food supplements, homeopathy and acupuncture $(15,18,19)$. In our study, patients mostly had cupping and leech therapy. The most common group of patients who use CAT in dermatological diseases were found to be psoriasis vulgaris, acne vulgaris and warts in a study conducted in Turkey(17). Generally, the rate of using CAT was found to be high in elderly patients, women and highly educated (18). In our study, $32 \%$ of men, $24 \%$ of women, $30 \%$ of PEG, $23 \%$ of HEG, $28 \%$ of $\leq 40$, and $24 \%$ of $>40$ used CAT. Although there was no statistically significant difference, it was seen in our study that men, PEG and young people applied to CAT method more frequently.

It is a fact that with the introduction of the Internet into our lives, we, physicians receive more questions from patients. Often, people search for what they don't know and wonder on the internet, where they can easily access it. $64 \%$ of our patients had searched their disease on the internet before coming to the hospital. However, the majority of patients $(78 \%)$ relied on their physicians if the information they found on the internet conflict with the doctor. The rate of HEG and younger patients were higher on internet research. The young and highly educated people may access the internet more easily. Especially young patients have more free time, they may easily access the internet even from the phone and they have more control over the technology.

One of the interesting questions about the dermatological myths was that $61 \%$ of the patients thought that they could sunbathe after applying sunscreen. We think that the society should be seriously educated about this situation which is against the philosophy of using sunscreen. We, dermatologists know that most of the patients who come with itching complaint request allergy tests. In our study, it was observed that $64 \%$ of patients thought this way. Patients should also be trained that it is not meaningful to have an allergy test in every itchy disease. While topical treatments such as cream and lotion are very important in dermatological diseases, $1 / 4$ of the patients stated that they did not like to use these treatments and $1 / 5$ of them thought that they did not work. We think that this issue should be emphasized and it should be explained that topical drugs are also a treatment method.

The limitation of the study is that it is conducted in only one center. A larger population with different geographical regions may be reached with a multicenter study.

\section{Conclusion}

Although the patients who applied to the dermatology outpatient clinic heard the name of the diseases that are relatively common in the society, they did not have much information about the rarely seen diseases. They needed more training, especially about contagious diseases, and that they cannot sunbathe after using sunscreen. Most people did not think of applying to the dermatology outpatient clinic in sexually transmitted diseases. They still had an interest in CAT methods and started to investigate their diseases in this way with the increasing use of the internet in recent years. The vast majority, however, relied more on doctor information than on the Internet.

\section{Acknowledgment}

We would like to thank Onurcan Şahin, PhD who made the statistics of our study, for his contributions. 


\section{References}

1. Ben-Aharon I, Goshen-Lago T, Turgeman I, et al. Young patients with cancer and a digital social network: the voice beyond the clinic. ESMO Open. 2020;5:e000651. Doi: 10.1136/ esmoopen-2019-000651

2. Koo K, Nagayah R, Begum S, et al. The use of complementary and alternative medicine in children with atopic eczema at a tertiary care centre in Malaysia. Complement Ther Med. 2020;49:102355. Doi: 10.1016/j.ctim.2020.102355

3. Chee $A$, Branca $L$, Jeker $F$, et al. When life is an itch: What harms, helps and heals from the patients' perspective? Differences and similarities among skin diseases. Dermatol Ther. 2020;33:e13606. Doi: 10.1111/dth.13606

4. Papadopoulos I. Comparative Study of Dermatological Diseases of the Elderly in Relation to the Rest Population. Clin Cosmet Investig Dermatol. 2020;13:173-8. Doi: 10.2147/CCID.S242294

5. Kayiran MA and Akdeniz N. Diagnosis and treatment of urticaria in primary care. North Clin Istanb. 2019;6:93-9. Doi: 10.14744/ nci.2018.75010

6. Nguyen TV, Hong J and Prose NS. Compassionate care: enhancing physician-patient communication and education in dermatology: Part I: Patient-centered communication. J Am Acad Dermatol. 2013;68:353.e1-8. Doi: 10.1016/j.jaad.2012.10.059

7. Roberts JE, Smith AM, Wilkerson AH, et al. "Psychodermatology" knowledge, attitudes, and practice among health care professionals. Arch Dermatol Res. 2020;312:545-58. Doi: 10.1007/ s00403-020-02050-9.

8. İnan Yüksel E, Erdemir AV, Turan $E$, et al. Pregnancy Dermatoses and Treatments. Istanbul Med J 2011;12:30-5. Doi: 10.5505/1304.8503.2011.49469

9. Akpınar Kara Y. Demographic and Clinical Characteristics of Patients in Private Hospital Dermatology Clinic. Turkiye Klinikleri J Med Sci 2018;38:329-33. Doi:10.5336/medsci.2018-61316

10. Özçelik S, Kulaç İ, Yazıcı M, et al. Distribution of childhood skin diseases according to age and gender, a single institution experience. Turk Pediatri Ars 2018; 53:105-12. Doi:10.5152/ TurkPediatriArs.2018.6431

11. Svensson A, Ofenloch RF, Bruze $M$, et al. Prevalence of skin disease in a population-based sample of adults from five European countries. Br J Dermatol. 2018;178:1111-8. Doi: 10.1111/bjd.16248

12. Ross Jl, Snelling AM, Carnegie E, et al. Antibiotic-resistant acne: lessons from Europe. $\mathrm{Br} J$ Dermatol. 2003;148:467-78. Doi: 10.1046/j.1365-2133.2003.05067.x

13. Koku Aksu A . Bulaşıcı Dermatolojik Hastalıkların Kontrolü Ve Halk Sağlığı Açısından Önemi. Estüdam Halk Sağlığı Dergisi. 2019;4:82-9. Doi: 10.35232/estudamhsd.528241

14. Grønhøj C, Jakobsen KK, Wingstrand VL, et al. Association between head and neck cancer and sexually transmitted diseases: a Danish nationwide, case-control study. Acta Otolaryngol. 2020;140:615-9. Doi:10.1080/00016489.2020.1748709

15. Ernst $\mathrm{E}$. The usage of complementary therapies by dermatological patients: a systematic review. Br J Dermatol. 2000;142:857-61. Doi: 10.1046/j.1365-2133.2000.03463.x

16. Smith N, Weymann A, Tausk FA, et al. Complementary and alternative medicine for psoriasis: a qualitative review of the clinical trial literature. J Am Acad Dermatol 2009;61:841-56. Doi: 10.1016/j.jaad.2009.04.029

17. Kutlu S, Ekmekçi TR, Köşlü A, et al. Complementary and alternative medicine among patients attending to dermatology outpatient clinic. Turkiye Klinikleri J Med Sci 2009;29:1496-502.
18. Boing AC, Ribeiro Santiago PH, Tesser CD, et al. Prevalence and associated factors with integrative and complementary practices use in Brazil. Complement Ther Clin Pract. 2019;37:1-5. Doi: 10.1016/j.ctcp.2019.07.009

19. Demirci GT, Altunay I, Küçükünal A, et al. Complementary and alternative medicine usage in skin diseases and the positive and negative impacts on patients. Turk J Dermatol 2012;6:150-4. Doi: $10.5152 /$ tdd. 2012.32 